\title{
Typical synoptic situations and their impacts on the wintertime air pollution in the Guanzhong basin, China
}

\author{
Naifang Bei ${ }^{1,2}$, Guohui Li $^{2}$, Ru-Jin Huang ${ }^{2,3}$, Junji Cao ${ }^{2}$, Ning Meng ${ }^{1}$, Tian Feng ${ }^{1,2}$, Suixin Liu ${ }^{2}$, Ting Zhang ${ }^{2}$, \\ Qiang Zhang ${ }^{4}$, and Luisa T. Molina ${ }^{5}$ \\ ${ }^{1}$ School of Human Settlements and Civil Engineering, Xi'an Jiaotong University, Xi'an, China \\ ${ }^{2}$ Key Laboratory of Aerosol Chemistry and Physics, SKLLQG, Institute of Earth Environment, \\ Chinese Academy of Sciences, Xi'an, China \\ ${ }^{3}$ Laboratory of Atmospheric Chemistry, Paul Scherrer Institute (PSI), 5232 Villigen, Switzerland \\ ${ }^{4}$ Department of Environmental Sciences and Engineering, Tsinghua University, Beijing, China \\ ${ }^{5}$ Molina Center for the Energy and the Environment, La Jolla, CA, USA \\ Correspondence to: Naifang Bei (bei.naifang@mail.xjtu.edu.cn) \\ and Guohui Li (ligh@ieecas.cn)
}

Received: 12 September 2015 - Published in Atmos. Chem. Phys. Discuss.: 15 January 2016

Revised: 27 May 2016 - Accepted: 31 May 2016 - Published: 14 June 2016

\begin{abstract}
Rapid industrialization and urbanization have caused severe air pollution in the Guanzhong basin, northwestern China, with heavy haze events occurring frequently in recent winters. Using the NCEP reanalysis data, the large-scale synoptic situations influencing the Guanzhong basin during wintertime of 2013 are categorized into six types to evaluate the contribution of synoptic situations to the air pollution, including "north-low", "southwesttrough", "southeast-high", "transition", "southeast-trough", and "inland-high". The FLEXPART model has been utilized to demonstrate the corresponding pollutant transport patterns for the typical synoptic situations in the basin. Except for "southwest-trough" and "southeast-high" (defined as favorable synoptic situations), the other four synoptic conditions (defined as unfavorable synoptic situations) generally facilitate the accumulation of air pollutants, causing heavy air pollution in the basin. In association with the measurement of $\mathrm{PM}_{2.5}$ (particulate matter with aerodynamic diameter less than $2.5 \mu \mathrm{m}$ ) in the basin, the unfavorable synoptic situations correspond to high $\mathrm{PM}_{2.5}$ mass concentrations or poor air quality and vice versa. The same analysis has also been applied to winters of 2008-2012, which shows that the basin was mainly influenced by the unfavorable synoptic situations during wintertime leading to poor air quality. The WRFCHEM model has further been applied to simulate the selected 6 days representing the typical synoptic situations dur-
\end{abstract}

ing the wintertime of 2013, and the results generally show a good agreement between the modeled distributions and variations of $\mathrm{PM}_{2.5}$ and the corresponding synoptic situations, demonstrating reasonable classification for the synoptic situations in the basin. Detailed meteorological conditions, such as temperature inversion, low-level horizontal wind speed, and planetary boundary layer, all contribute to heavy air pollution events in the basin under unfavorable synoptic conditions. Considering the proportion of occurrence of unfavorable synoptic situations during wintertime, reduction of emissions is the optimum approach to mitigate the air pollution in the Guanzhong basin.

\section{Introduction}

Elevated atmospheric pollutants, such as particulate matter $(\mathrm{PM})$ and ozone $\left(\mathrm{O}_{3}\right)$, exert deleterious impacts on human health and environment (e.g., Penner et al., 2001; Pope and Dockery, 2006; J. Zhang et al., 2010). Over the past 3 decades, with tremendous economic growth in China, rapid industrialization and urbanization have caused severe air pollution, as reflected in the heavy haze event that often occurs in the north of China, particularly during wintertime (e.g., Chan and Yao, 2008; Fang et al., 2009; Gao et al., 2011; Liu et al., 2013; Zhao et al., 2013; Huang et al., 2014; Fu et al., 
2014; Guo et al., 2014; Han et al., 2014; Zhang et al., 2015; Yang et al., 2015). Guanzhong basin is located in the northwest of China, nestled between the Qinling Mountains in the south and the Loess Plateau in the north. The unique topography facilitates the accumulation of air pollutants and, with the fast-growing industries and city expansions, heavy air pollution frequently engulf the basin (e.g., Cao et al., 2009; Shen et al., 2011).

Numerous studies have demonstrated that the meteorological conditions play an important role in the formation, transformation, diffusion, transport, and removal of the atmospheric pollutants (e.g., Seaman, 2000; Solomon et al., 2000; de Foy et al., 2005, 2006; Bei et al., 2008, 2010, 2012, 2013). When the emissions of pollutants remain invariable, transformations in the chemical state of the atmosphere are principally determined by the meteorological conditions. Recent advances in understanding the role of meteorological conditions in the air pollution formation in China have mainly concentrated in the regions of Beijing-Tianjin-Hebei, the Pearl River Delta, and the Yangtze River Delta (e.g., Wu et al., 2008, 2013; Wang et al., 2009; Q. H. Zhang et al., 2010; Gao et al., 2011; Zhang et al., 2012; H. Wang et al., 2014; L. Wang et al., 2014; Zhang et al., 2015). Wang et al. (2009) have shown that $\mathrm{O}_{3}$ decrease at a Beijing rural site during the 2008 Olympics is attributed to the favorable meteorological condition compared with the same period in 2006 and 2007. Q. H. Zhang et al. (2010) have proposed that, during the 2008 Olympics, the atmospheric visibility improvements are likely caused by the decrease of atmospheric relative humidity compared to the same period in the previous 5 years. Using a coupled meteorology-chemistry model, Gao et al. (2011) have further pointed out that meteorological conditions are as important as emission controls in reducing aerosol concentrations in Beijing during the 2008 Olympics. Wu et al. (2008) have performed analysis of the typical haze and clean weather processes over the Pearl River Delta in 2004 and 2005; they found that the regional haze formation is highly correlated to the regional calm wind process while the cleaning process is influenced by the strong advection transport. Additionally, Wu et al. (2013) have classified two typical weather conditions associated with poor air quality over the Pearl River Delta, including the warm period before a cold front and the subsidence period controlled by a tropical cyclone during two intensive observations in 2004 and 2006. L. Wang et al. (2014) have demonstrated that recirculation and regional transport, along with poor diffusion conditions and high humidity favorable for hygroscopic growth of secondary aerosols, caused the extremely high levels of $\mathrm{PM}_{2.5}$ in Beijing during January 2013. Zhang et al. (2015) have also suggested that the weak transport/diffusion was an important factor for the haze occurrences.

The circulation-based classification is an approach to identify synoptic weather categories through determining the circulation types from sea level pressure, geopotential height, or wind fields (Huth et al., 2008). Since the meteorological fields that affect the air quality are generally closely interrelated and strongly controlled by the synoptic-scale circulation, the circulation classification has been extensively used in environmental studies, especially in the middle and highlatitude regions where local weather conditions are mainly determined by the day-to-day synoptic circulation variability (e.g., Jacobeit, 2010; Huth et al., 2008). For example, Bei et al. (2013) have classified the typical synoptic situations and the associated plume transport patterns in the US-Mexico border region along the Pacific Ocean, and they found that the plume transport directions are generally consistent with the prevailing wind directions at $850 \mathrm{hPa}$. However, only a few studies have been performed to investigate the synoptic weather classification in China (Huth et al., 2008). Cheng et al. (2001) have demonstrated that high $\mathrm{O}_{3}$ concentrations in Taiwan are related to anticyclone synoptic systems and a tropical low-pressure system moving from the south of Taiwan. Recent studies have also indicated that the developing and different parts of an anticyclonic system play an important role in regulating air quality (Chen et al., 2008; Wei et al., 2011). However, the above-mentioned studies are all based on case studies during a short period using subjective procedure. Zhang et al. (2012) have verified the relationship between surface circulation pattern and air quality in Beijing and the surrounding areas over 10 years using a synoptic approach based on an objective classification procedure (Philipp et al., 2010). The results have demonstrated that significant differences exist in the local meteorology and footprints of $48 \mathrm{~h}$ backward trajectories among various circulation types, and synoptic-scale circulations are the principal drivers of day-to-day variations in pollutant concentrations over Beijing and surrounding areas during the emission control period.

Previous studies have examined the composition, characteristics, and sources of the atmospheric pollutants in the Guanzhong basin (e.g., Cao et al., 2009, 2012; Shen et al., 2010, 2011). However, few studies have been performed to comprehensively explore the relationship between air pollution and the meteorological conditions at both synoptic and local scales in this area. Therefore, it is imperative to examine the role of the specific meteorological conditions in the formation of heavy air pollution in this area to support design and implementation of emission control strategies.

The purpose of the present study was to categorize the large-scale synoptic weather systems that impact the Guanzhong basin in the winter along with the measurements of pollutants in the basin using a subjective classification procedure, which determines the circulation types from the geopotential height and wind fields at $850 \mathrm{hPa}$. The air quality conditions associated with various synoptic situations are simulated using the WRF-CHEM model developed by Li et al. $(2010,2011 \mathrm{a}, \mathrm{b})$ to evaluate the contributions of the particular meteorological conditions to the severe air pollution. The models and methodology used in this study are intro- 
duced in Sect. 2. The main results are presented in Sect. 3. Conclusions and discussions are given in Sect. 4.

\section{Data, models, and methodology}

\subsection{Meteorological and $\mathbf{P M}_{2.5}$ data}

The National Centers for Environmental Prediction (NCEP) final operational global gridded analysis $(\mathrm{FNL})\left(1^{\circ} \times 1^{\circ}\right)$ is used to categorize the large-scale synoptic weather systems influencing the Guanzhong basin during the period from 2008 to 2013 through the subjective procedure (introduced in Sect. 2.3). The geopotential height and wind fields at $850 \mathrm{hPa}$ are applied to identify the synoptic situations that affect the plume transport patterns in the basin.

Continuous daily $\mathrm{PM}_{2.5}$ measurements have been performed at the Institute of Earth Environment, Chinese Academy of Sciences (IEECAS) in Xi' an, China, since 2003. Additionally, since January 2013, China's Ministry of Environmental Protection (China MEP) has commenced releasing the real-time hourly concentrations of $\mathrm{PM}_{2.5}$. A total of 33 monitoring sites are distributed in the Guanzhong basin (Fig. 1b). The daily $\mathrm{PM}_{2.5}$ measurement at IEECAS site from 2008 to 2012 and the hourly $\mathrm{PM}_{2.5}$ measurement released by China MEP from 2013 to 2014 are used to validate the categorized synoptic situations influencing the basin. The realtime $\mathrm{PM}_{2.5}$ used in this study can be accessed at the website http://106.37.208.233:20035/. One can also access the historic profile of observed ambient pollutants through visiting http://www.aqistudy.cn/ (Ministry of Environmental Protection, 2013a, b).

\subsection{FLEXPART-WRF and WRF-CHEM models}

In order to analyze the corresponding pollutant transport patterns under the typical categorized synoptic situations, the FLEXPART model is employed to calculate the forward Lagrangian particle dispersion (Stohl et al., 1998; Fast and Easter, 2006), which is driven by the output from the WRF model (Skamarock et al., 2008). The FLEXPART model is set up with releases of 6000 computational particles within a grid cell of $10 \mathrm{~km} \times 10 \mathrm{~km} \times 0.02 \mathrm{~km}$ centered at Xi'An urban area in the morning. Tracer particles are released continuously from 04:00 to 10:00 BJT (Beijing time) of the day, and traced until 04:00 BJT of next day. For the convenience, all the time used hereafter is BJT. The WRF model adopts one grid with horizontal resolution of $3 \mathrm{~km}$ and 35 sigma levels in the vertical direction. The grid cells used for the domain are $201 \times 201$ (Fig. 1a). The selected 6 days, representing six categorized typical synoptic situations of the Guanzhong basin during wintertime of 2013, are simulated. They are initialized at 20:00 BJT on each day and integrated for $36 \mathrm{~h}$. The NCEP FNL analysis data $\left(1^{\circ} \times 1^{\circ}\right)$ are used to produce the initial and boundary conditions for the WRF model. The physical process parameterization schemes used
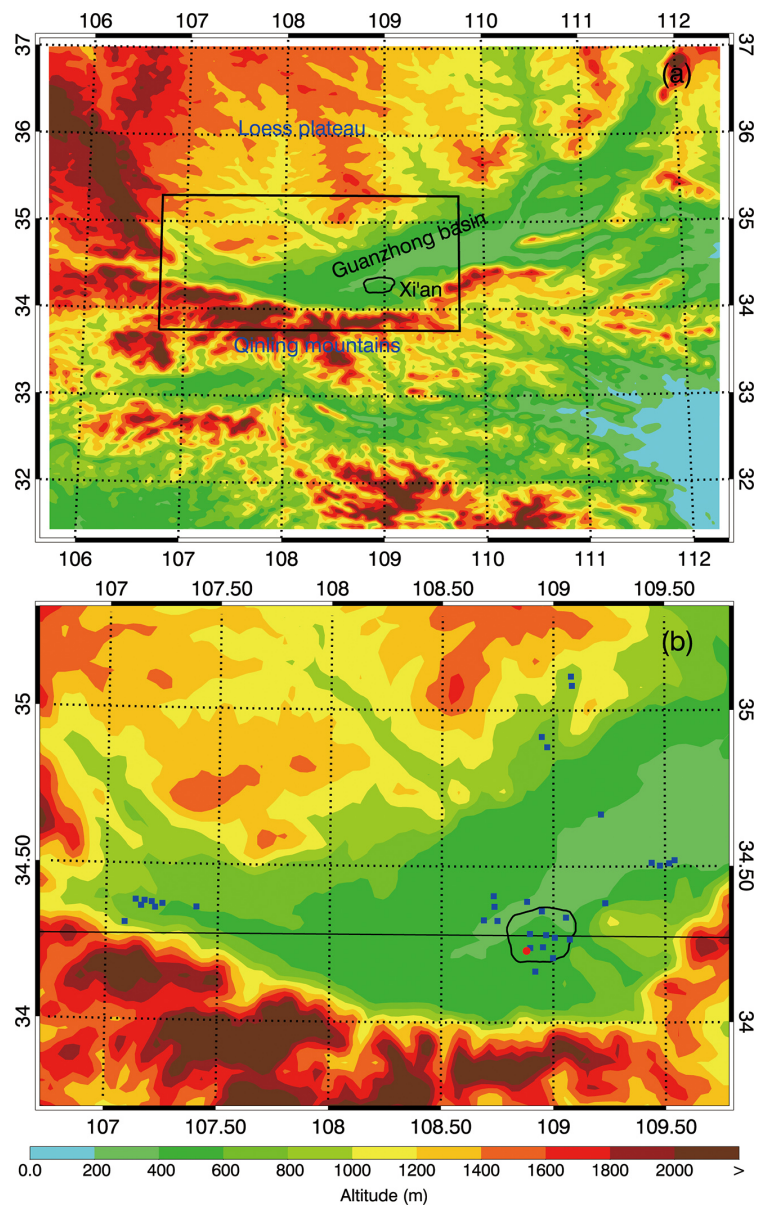

Figure 1. (a) WRF and WRF-CHEM model simulation domain with topography and (b) geographic distributions of ambient monitoring stations. In panel (b), the blue filled squares are the ambient monitoring sites, the red filled circle is the IEECAS site, and the cross line is the position of the cross section shown in Fig. 7. The color contour in both panels denotes the terrain height.

in simulations included the Grell-Devenyi ensemble scheme for cumulus scheme (Grell and Devenyi, 2002), the WRF Single Moment (WSM) three-class microphysics (Hong et al., 2004), and Mellor-Yamada-Janjíc (MYJ) TKE scheme (Janjic, 2002) for the planetary boundary layer (PBL) processes.

The WRF-CHEM model has been used to further simulate the selected 6 days representing the typical categorized synoptic situations and to verify the particular meteorological conditions during the severe air pollution events in the Guanzhong basin. A specific version of the WRF-CHEM model (Grell et al., 2005) is used in the present study, which was developed by Li et al. (2010, 2011a, b, 2012) at the Molina Center for Energy and the Environment, with a new flexible gas phase chemical module and the CMAQ (version 4.6) aerosol module developed by US EPA (Binkowski and Roselle, 2003). The inorganic aerosols are simulated in 
Table 1. Synoptic categories influencing the Guanzhong basin during the wintertime of 2013.

\begin{tabular}{|c|c|c|c|}
\hline Categories & Date* $^{*}$ & Sum & Percentage $(\%)$ \\
\hline North-low & $\begin{array}{lllll}20131217 & 20131208 & 20140110 & 20140111 & 20140102 \\
20140106 & 20140204 & 20140205 & 20140206 & 20140215 \\
20140216 & 20140217 & 20140224 & 20140225 & 20140228 \\
20140208 & & & & \end{array}$ & 16 & 17.8 \\
\hline Southwest-trough & $\begin{array}{lllll}20131201 & 20131205 & 20131209 & 20131211 & 20131212 \\
20131215 & 20131231 & 20140103 & 20140104 & 20140119 \\
20140120 & 20140108 & 20140112 & & \end{array}$ & 13 & 14.4 \\
\hline Southeast-high & 20131210201312262014010720140227 & 4 & 4.4 \\
\hline Transition & $\begin{array}{lllll}20131202 & 20131207 & 20131214 & 20131230 & 20140101 \\
20140116 & 20140127 & 20140130 & 20140201 & 20140202 \\
20140207 & & & & \end{array}$ & 11 & 12.2 \\
\hline Southeast-trough & 2013120420140123201401292014013120140226 & 5 & 5.6 \\
\hline Inland-high & $\begin{array}{lllll}20131203 & 20131206 & 20131213 & 20131219 & 20131221 \\
20131222 & 20131223 & 20131224 & 20131216 & 20131225 \\
20131218 & 20131220 & 20131227 & 20131229 & 20131228 \\
20140105 & 20140113 & 20140118 & 20140122 & 20140125 \\
20140115 & 20140121 & 20140126 & 20140128 & 20140109 \\
20140114 & 20140117 & 20140124 & 20140214 & 20140219 \\
20140211 & 20140210 & 20140213 & 20140220 & 20140221 \\
20140222 & 20140223 & 20140218 & 20140212 & 20140209 \\
20140203 & & & & \end{array}$ & 41 & 45.6 \\
\hline
\end{tabular}

* The format of date is YYYYMMDD, in which YYYY, MM, and DD represent year, month, day, respectively.

the WRF-CHEM model using ISORROPIA ("equilibrium" in Greek, here referred to as an improved thermodynamic equilibrium aerosol model) version 1.7 (http://nenes.eas. gatech.edu/ISORROPIA/). The secondary organic aerosol (SOA) formation is simulated using a non-traditional SOA model including the volatility basis-set modeling method in which primary organic components are assumed to be semivolatile and photochemically reactive and are distributed in logarithmically spaced volatility bins (Li et al., 2011a). Detailed description of the WRF-CHEM model can be found in Li et al. (2010, 2011a, b, 2012). The meteorological setup in the WRF-CHEM model simulations is same as those in the WRF model, except that the spin-up time of the WRF-CHEM model is 1 day. The chemical initial and boundary conditions for the WRF-CHEM model simulations are interpolated from the $6 \mathrm{~h}$ output of a global chemical transport model for $\mathrm{O}_{3}$ and related chemical tracers (MOZART) (Horowitz et al., 2003). The anthropogenic emission inventory developed by Zhang et al. (2009) is used in the study, including contributions from agriculture, industry, power, residential and transportation sources. The MEGAN model developed by Guenther et al. (2006) is used to calculate online biogenic emissions.

\subsection{Classification method}

The subjective procedure is used to categorize the synoptic situations that affect the plume transport patterns in the Guanzhong basin. The synoptic weather system is first identified according to the geopotential height and wind fields on $850 \mathrm{hPa}$. Then the detailed position of the basin to the weather system can be determined. For example, when the basin is located in the southwest of a trough, the synoptic situation is categorized as "southwest-trough"; when a highpressure system controls the basin, the synoptic situation is defined as "inland-high". However, since the synoptic situations are not very clear-cut at times, the FLEXPART-WRF model is further used to calculate the plume transport patterns in the basin under different synoptic situation classifications. When the transition of the weather system influencing the basin for 1 day exists, the synoptic categorization is determined by the plume transport patterns in the basin. For example, on some day, the weather system influencing the basin transits from "inland-high" to "southwest-trough". The calm and stable situations induced by "inland-high" facilitate the pollutants accumulation in the basin, but the dry and cold northwest winds caused by "southwest-trough" is subject to evacuate the pollutants in the basin. When the FLEXPART-WRF model results show that the plume moves outside of the basin, the synoptic situation is categorized as 


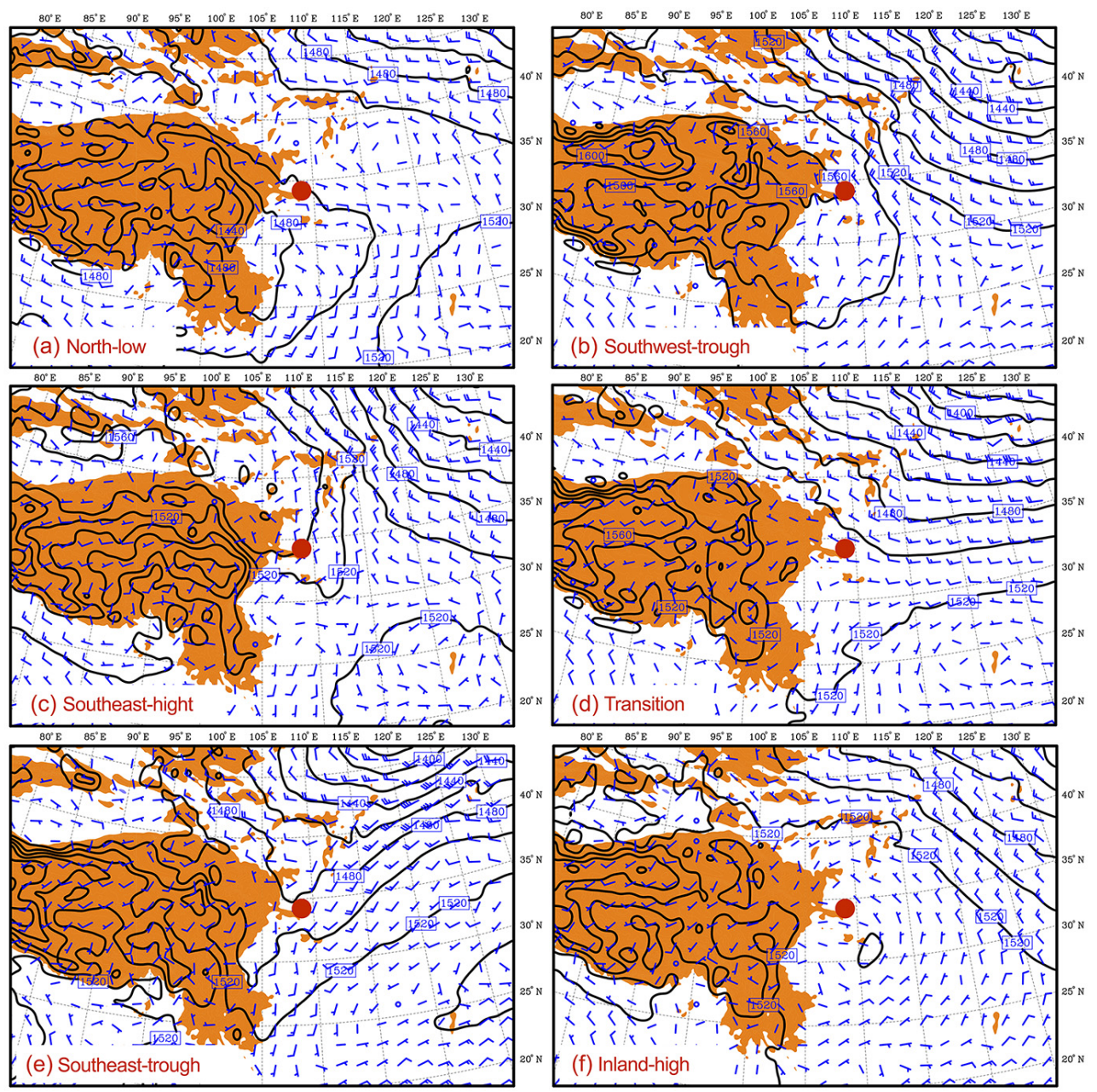

Figure 2. Composite distributions of winds and geopotential heights on $850 \mathrm{hPa}$ at 08:00 BJT for the categories of (a) "north-low", (b) "southwest-trough", (c) "southeast-high", (d) "transition", (e) "southeast-trough", and (f) "inland-high". The red filled circle is Xi' an. The orange shading represents the terrain height over $1500 \mathrm{~m}$.

"southwest-trough" for the day, otherwise it is classified as "inland-high". Additionally, the occurrence of precipitation is not considered yet in the categorization, which can efficiently wash out pollutants in the atmosphere. Therefore, it is worth noting that, on different days which are grouped into the same category, the pollutants behavior might be quite different due to the weather system transition or precipitation occurrence.

\section{Results}

NCEP FNL reanalysis data, the model output from the FLEXPART model, and the $\mathrm{PM}_{2.5}$ measurements in the Guanzhong basin are used to explore the typical meteorological synoptic situations and the corresponding plume transport patterns. Using the model output from the WRF-CHEM model, we have further investigated the local meteorological conditions, including the PBL height, low-level wind speed, and inversion layer, and their potential impacts on the air pollution formation process in the basin.

\subsection{Classification of the typical synoptic situations and the corresponding pollutant transport patterns}

Based on the NCEP FNL reanalysis data, we have initially performed the analysis of the synoptic situations during the wintertime of 2013 using the $850 \mathrm{hPa}$ wind and geopotential height fields. Here the wintertime is defined as December of the year to February of the following year. Six typical synoptic situations are categorized; these are "north-low", "southwest-trough", "southeast-high", "transition", "southeast-high", and "inland-high". The composite $850 \mathrm{hPa}$ wind and geopotential height fields are shown in Fig. 2 for each category. The detailed dates are shown in Table 1. The percentages of occurrence for the abovementioned six types are 17.8, 14.4, 4.4, 12.2, 5.6, and 

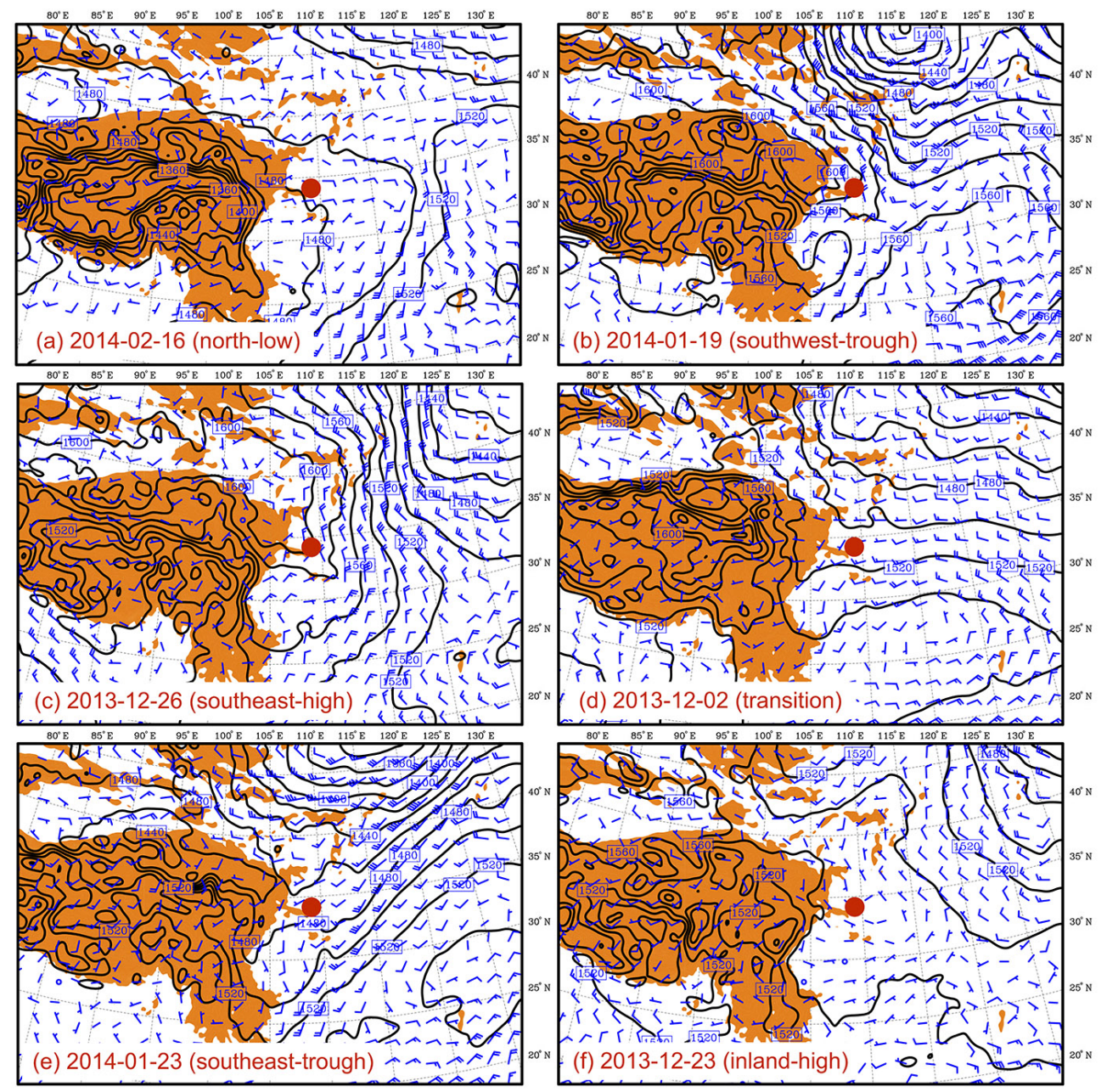

Figure 3. Distributions of winds and geopotential heights on $850 \mathrm{hPa}$ at 08:00 BJT on (a) 16 February 2014 ("north-low"), (b) 19 January 2014 ("southwest-trough"), (c) 26 December 2013 ("southeast-high"), (d) 2 December 2013 ("transition"), (e) 23 January 2014 ("southeasttrough"), and (f) 23 December 2013 ("inland-high"). The red filled circle is Xi' an. The orange shading represents the terrain height over $1500 \mathrm{~m}$.

$45.6 \%$, respectively, indicating that the "inland-high" is the dominant wintertime synoptic situation influencing the Guanzhong basin.

For discussion convenience, the following 6 days are selected to represent the above six typical synoptic situations: (1) 16 February 2014 ("north-low"), (2) 19 January 2014 ("southwest-trough"), (3) 26 December 2013 ("southeasthigh"), (4) 2 December 2013 ("transition"), (5) 23 January 2014 ("southeast-trough"), and (6) 23 December 2013 ("inland-high"). For the selection process, 3 days are first chosen for every category. The FLEXPART-WRF and WRFCHEM models are then used to simulate the pollutants transport pattern and $\mathrm{PM}_{2.5}$ variations and distributions on the 3 selected days in each category. In general, the simulation results from the two models are similar in the same category, but uncertainties still exist, caused by the weather system transition or occurrence of precipitation. Finally, the most typical day for each category is selected for further analysis and model simulations. The synoptic patterns of the selected 6 days, shown in Fig. 3, are similar to those in Fig. 2. In the case of the "north-low" (Fig. 3a), the Guanzhong basin is generally located in the north of the low on $850 \mathrm{hPa}$ and the weak east wind is prevalent aloft. Due to the blocking of the specific topography (Fig. 1a), the convergence or stagnant conditions are frequently formed, which is not favorable for the dispersion of air pollutants. However, heavy air pollution might not emerge in the basin due to the occurrence of precipitation, which is caused by the favorable dynamical conditions that can efficiently clean up the pollutants. For the category of "southwest-trough" (Fig. 3b), the basin is located in the southwest of the trough on $850 \mathrm{hPa}$ and the northwest wind is prevailing over the basin. The cold and dry air from the northwest effectively purges the air pollutants formed in the basin and also brings blue sky to the basin. For 


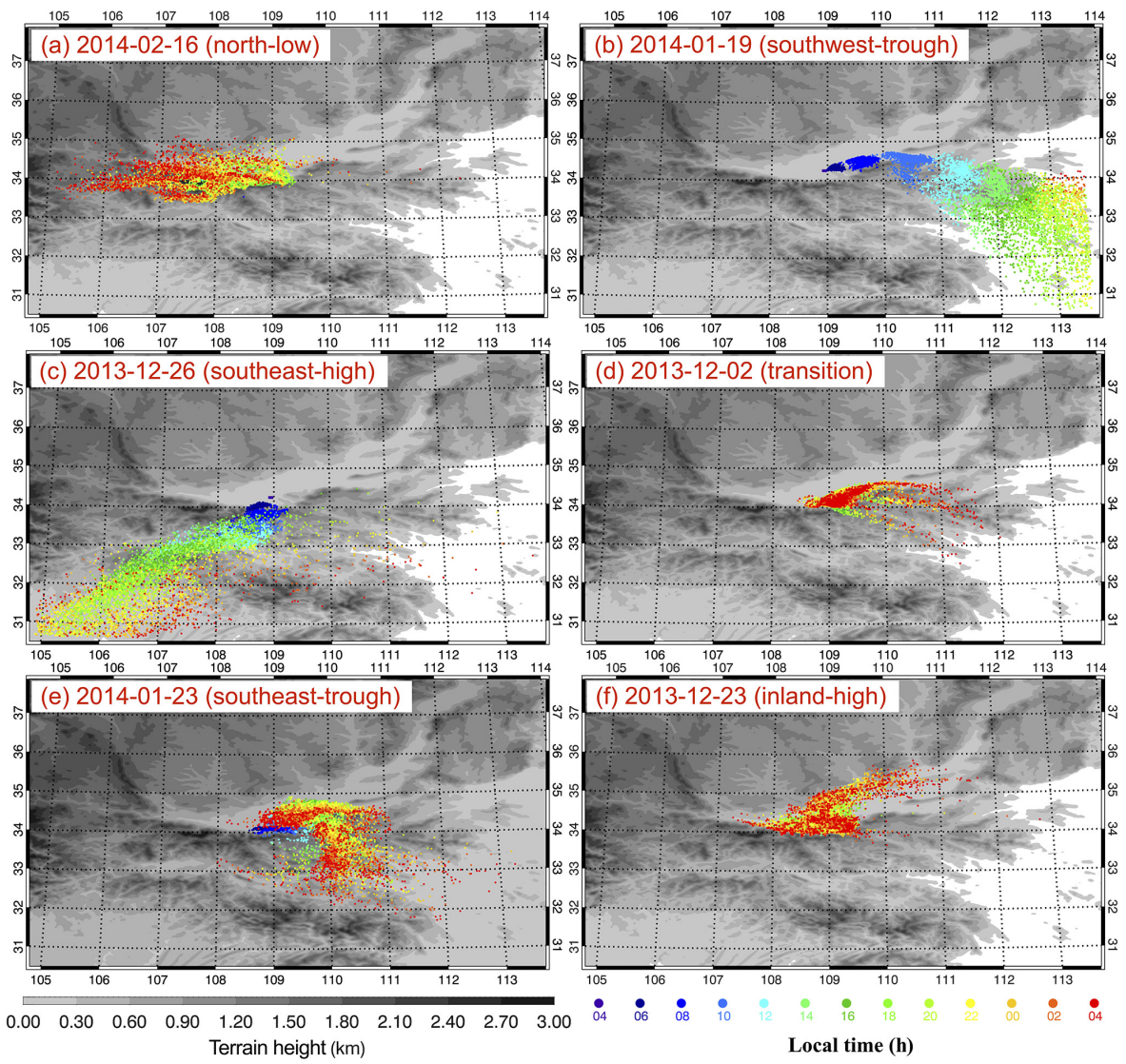

Figure 4. Twenty-four-hour plume transport patterns initialized from 04:00 BJT on (a) 16 February 2014 ("north-low"), (b) 19 January 2014 ("southwest-trough"), (c) 26 December 2013 ("southeast-high"), (d) 2 December 2013 ("transition"), (e) 23 January 2014 ("southeasttrough"), and (f) 23 December 2013 ("inland-high"). The gray contour denotes the terrain height. The color dots represent the released particles at different time.

"southeast-high" (Fig. 3c), the basin is located in the southeast of the high at $850 \mathrm{hPa}$, which originates the prevalent northeasterly or northwesterly winds, transporting the pollutants outside of the basin and remarkably improving the air quality. When the basin is situated in the transition area between the trough in the north and the high in the south on $850 \mathrm{hPa}$, the synoptic situation is defined as "transition" (Fig. 3d). The prevailing winds over the basin are generally westerly, but the west wind is significantly attenuated by the topography in the basin and often transformed to be calm or disordered. The atmospheric pollutants are subject to be transported to the east of the basin but are more likely to be trapped in the basin, causing heavy air pollution. Additionally, under the condition of "transition", the meteorological fields in the basin are also coordinately adjusted with the development of the trough in the north and the high in the south on $850 \mathrm{hPa}$. Under the condition of "southeast-trough" (Fig. 3e), the basin is affected by the trough on $850 \mathrm{hPa}$ in the northwest, and the southwest wind is dominant aloft. The weak south winds and convergence formed in front of the trough tend to withhold the air pollutants in the basin, significantly deteriorating the air quality. For "inland-high" (Fig. 3f), the basin is controlled by the inland high at $850 \mathrm{hPa}$, and the prevailing wind is varied over the basin, depending on the detailed location of the high. The situation of weak winds, subsidence, and the stable stratification facilitates the accumulation of atmospheric pollutants, often causing severe air pollution in the basin.

Figure 4 displays the $24 \mathrm{~h}$ plume transport patterns initialized from 04:00 BJT during the above-mentioned 6 representative days. The particles released in the morning in the urban area of Xi' an are generally transported within the PBL. Apparently, the particles can be transported outside of the basin only in the case of "southwest-trough" and "southeast-high" and the improvement of air quality in the basin is anticipated. For the remaining four synoptic categories, most of the released particles ramble in the basin, indicating buildup of the air pollutants.

The above analyses demonstrate that only two kinds of synoptic conditions ("southwest-trough" and "southeasthigh", defined as favorable synoptic situations hereafter) disperse pollutants efficiently and engender the good air qual- 
ity in the Guanzhong basin. The other four kinds of synoptic situations ("north-low", "transition", "southeast-trough", and "inland-high", defined as unfavorable synoptic situations hereafter) are generally favorable for the accumulation of the air pollutants either in horizontal or vertical directions, except in the case of the "north-low" with strong winds or precipitation or the "southeast-trough" with strong vertical mixing.

Figure 5 displays the average diurnal cycle of observed $\mathrm{PM}_{2.5}$ mass concentrations at 33 monitoring sites in the Guanzhong basin under the six synoptic categories during the wintertime of 2013. The favorable synoptic situations consistently correspond to low $\mathrm{PM}_{2.5}$ mass concentrations or relatively good air quality and vice versa. Under the unfavorable synoptic situations, the observed average $\mathrm{PM}_{2.5}$ mass concentrations generally range from 150 to $250 \mu \mathrm{g} \mathrm{m}^{-3}$, showing that the basin has experienced heavy air pollution. The $\mathrm{PM}_{2.5}$ mass concentrations for "north-low" are lower than those under the other three unfavorable synoptic situations, which is caused by the possible occurrence of precipitation in "northlow". For example, the synoptic patterns on 4-5 February 2014 are categorized as "north-low", but the observed average $\mathrm{PM}_{2.5}$ mass concentrations are less than $90 \mu \mathrm{g} \mathrm{m}^{-3}$ because of the precipitation washout during these 2 days. Although the favorable synoptic situations facilitate the evacuation of air pollutants in the basin, the observed average $\mathrm{PM}_{2.5}$ mass concentrations still exceed $35 \mu \mathrm{g} \mathrm{m}^{-3}$, indicating that the air quality in the basin barely reaches the "excellent" level. It should be noted that exceptional days exist beyond the six synoptic situations, demonstrating the complexity of atmospheric circulations.

Using the same method deployed in 2013, we have further classified the large-scale synoptic situations of the wintertime in the Guanzhong basin for the period from 2008 to 2012. The above-mentioned six typical synoptic situations influencing the Guanzhong basin during the wintertime from 2008 to 2012 are summarized in Table 2. Figure 6 displays the daily mean $\mathrm{PM}_{2.5}$ mass concentration averaged during the six typical synoptic situations from 2008 to 2012 at the IEECAS site. The percentage of total unfavorable synoptic situations during 2008 to 2012 is about $85 \%$, and corresponding daily $\mathrm{PM}_{2.5}$ mass concentrations exceed $200 \mu \mathrm{g} \mathrm{m}^{-3}$ (Fig. 6), indicating significant contribution from the large-scale meteorological conditions to the poor air quality in the basin. The "inland-high" dominates the synoptic situation in association with the poor air quality in the basin, with contribution around $43 \%$. The favorable situations constitute about $15 \%$ of the synoptic situation in the basin, which is anticipated to flush the basin and significantly improve the air quality. However, the observed daily $\mathrm{PM}_{2.5}$ mass concentrations during the favorable situations still exceed $75 \mu \mathrm{g} \mathrm{m}^{-3}$ and fail to reach the "good" level, indicating massive local emissions of pollutants and considerable contributions of background dust transported from Loess Plateau in the north.

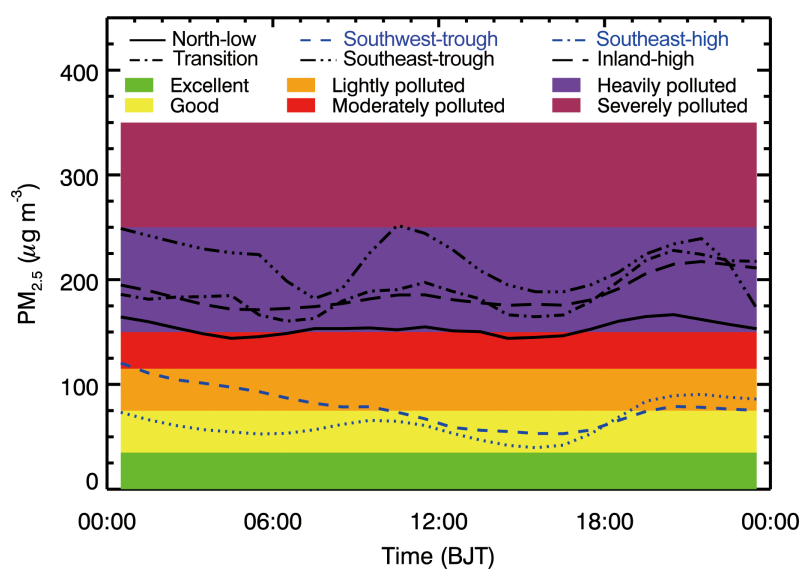

Figure 5. Diurnal cycle of observed $\mathrm{PM}_{2.5}$ mass concentrations averaged over 33 monitoring sites in the Guanzhong basin under the six synoptic categories during the wintertime of 2013.

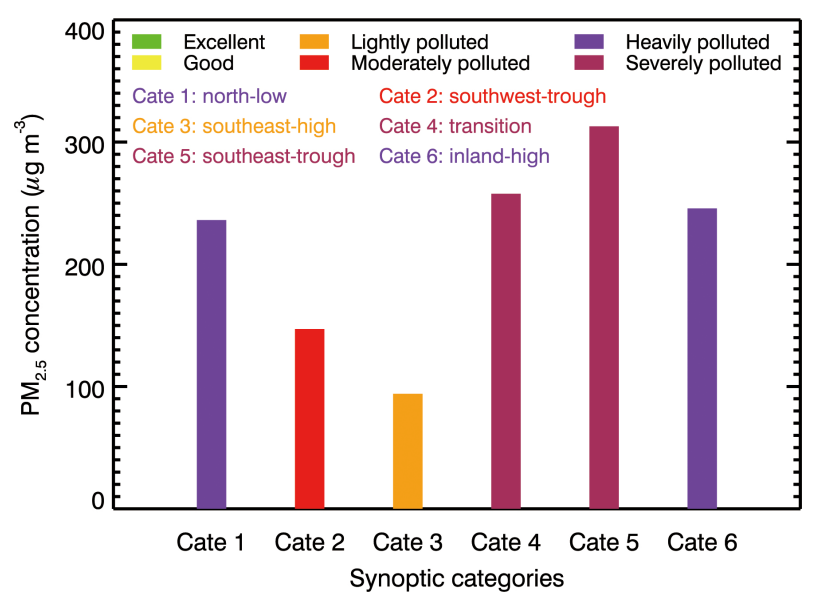

Figure 6. Daily mean $\mathrm{PM}_{2.5}$ mass concentration average during the six typical synoptic situations from 2008 to 2012 at the IEECAS site.

\subsection{Local meteorological conditions on the selected 6 days and their impact on the air quality}

The results of the FLEXPART model only explain the direct impact of the meteorological fields on the plume transport process since chemical processes are not considered in the model. The WRF-CHEM model is therefore used to simulate the air quality in the Guanzhong basin on the selected 6 days corresponding to the above-mentioned six typical synoptic situations.

Figure 7 shows the vertical distributions of temperature, wind vectors, and $\mathrm{PBL}$ height throughout $\mathrm{Xi}$ 'an along the east-west direction at 09:00 and 15:00 BJT during the selected 6 days in order to investigate the vertical atmospheric characteristics under the six typical synoptic situations. The vertical section shows that the depth of the basin is around $1 \mathrm{~km}$, suggesting that the local terrain (Loess Plateau and 
Table 2. Days and percentage of the six types of synoptic situations influencing the Guanzhong basin during the wintertime from 2008 to 2012.

\begin{tabular}{lrrrrrr}
\hline Categories & $\begin{array}{r}\text { North } \\
\text { low }\end{array}$ & $\begin{array}{r}\text { Southwest } \\
\text { trough }\end{array}$ & $\begin{array}{r}\text { Southeast } \\
\text { high }\end{array}$ & Transition & $\begin{array}{r}\text { Southeast } \\
\text { trough }\end{array}$ & $\begin{array}{r}\text { Inland } \\
\text { high }\end{array}$ \\
\hline 2008 & 14 & 8 & 2 & 15 & 11 & 40 \\
2009 & 17 & 6 & 6 & 14 & 18 & 29 \\
2010 & 14 & 10 & 8 & 8 & 6 & 41 \\
2011 & 16 & 6 & 10 & 5 & 3 & 52 \\
2012 & 22 & 9 & 1 & 15 & 13 & 31 \\
\hline Sum & 83 & 39 & 27 & 57 & 51 & 193 \\
\hline Percentage $(\%)$ & 18.4 & 8.7 & 6.0 & 12.7 & 11.3 & 42.9 \\
\hline
\end{tabular}
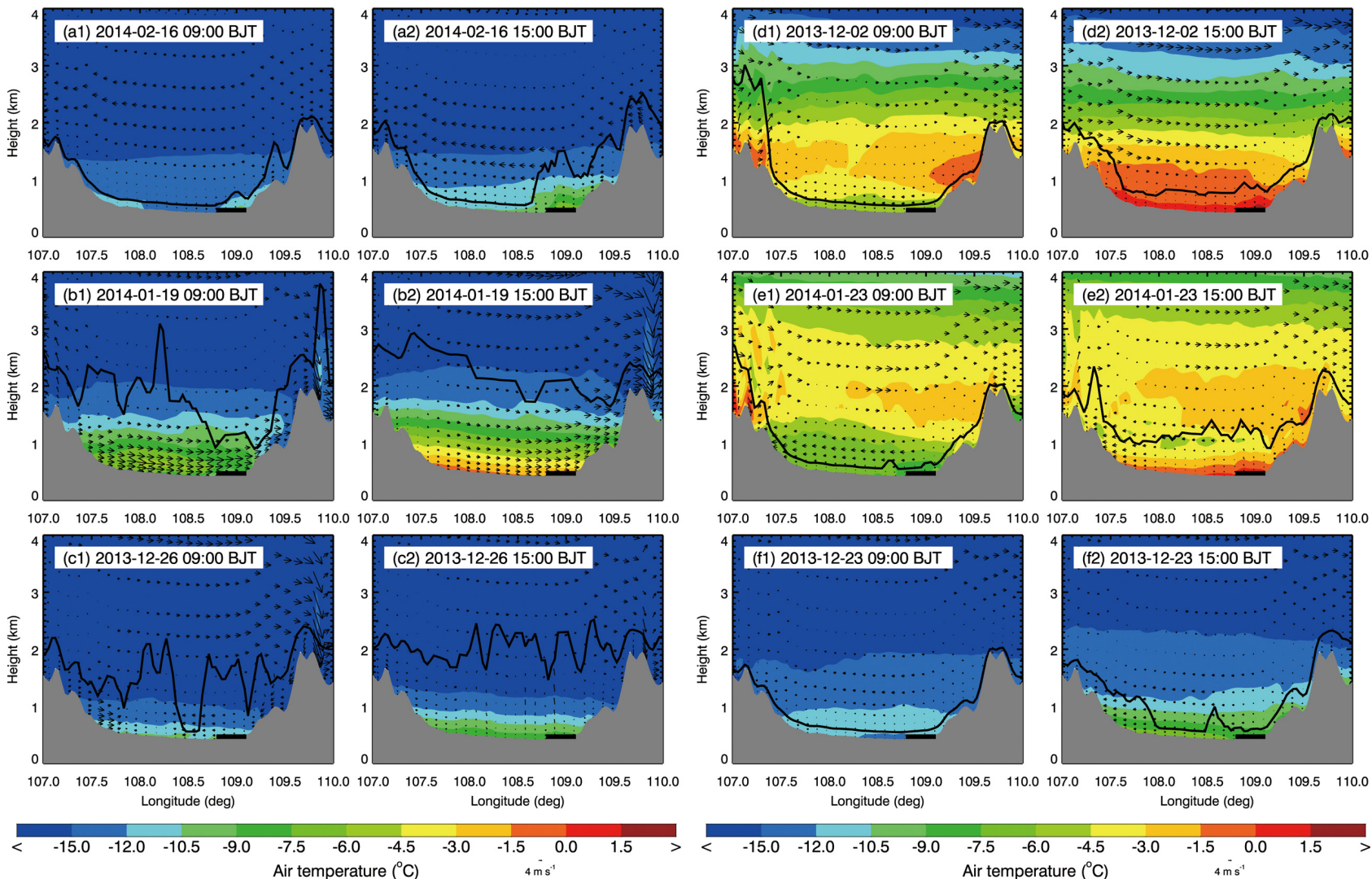
Longitude (deg) Longitude (deg)

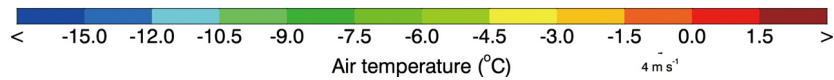

Figure 7. Vertical distributions of temperature, wind vectors, and PBL height along the cross line denoted in Fig. 1b at 09:00 and 15:00 BJT on (a) 16 February 2014 ("north-low"), (b) 19 January 2014 ("southwest-trough"), (c) 26 December 2013 ("southeast-high"), (d) 2 December 2013 (“transition”), (e) 23 January 2014 (“southeast-trough”), and (f) 23 December 2013 (“inland-high”). The black filled rectangle represents the urban area of Xi' an, China.

Qinling Mountains) has important impacts on the low-level wind fields inside the basin. Under unfavorable synoptic situations, the winds inside the basin are remarkably attenuated due to the influence of the terrain, favorable for trapping the air pollutants formed in the basin. In addition, at 09:00 BJT, temperature inversions in the case of unfavorable synoptic situations also impede the development of PBL, decreasing the diffusion of air pollutants in the vertical direction. At
15:00 BJT, the weak winds do not enhance the PBL development due to lack of the wind shear inside the basin and the thermal impact dominates the PBL height. The PBL on 2 December 2013 and 23 January 2014 is higher than that on 16 February 2014 and 23 December 2013 due to the lowlevel temperature discrepancy, and the impact of the urban heat island on the PBL height is also obvious. Therefore, the unfavorable synoptic situations are prone to trap the pollu- 
tants inside the basin due to inefficient horizontal transport and impeded vertical diffusion, leading to heavy air pollution in the basin. In the case of favorable synoptic situations, the strong horizontal wind (19 January 2014) or active vertical motion (26 December 2013) efficiently diffuse the pollutants in the horizontal or vertical directions and the high PBL also expedites the vertical exchange of air pollutants in the basin; thus good air quality is expected.

In order to investigate the detailed local meteorological conditions over the Guanzhong basin during the abovementioned 6 days, we have further analyzed the low-level (below $850 \mathrm{hPa}$ ) horizontal wind speed and PBL height averaged over the Guanzhong basin (the averaged domain indicated in Fig. 1). Figure 8 shows the time evolutions of the area averaged low-level wind speed and PBL height over the basin on the selected 6 days. In general, under favorable synoptic situations, the occurrence of strong horizontal winds speeds up the evacuation of pollutants, such as on 19 January 2014, the average wind speed is around $8 \mathrm{~m} \mathrm{~s}^{-1}$. In addition, the daily average PBL height exceeds $500 \mathrm{~m}$, facilitating the pollutants dispersion in the vertical direction. However, under the unfavorable conditions, except on 2 December 2013, the weak horizontal winds inefficiently disperse the pollutants; i.e., the horizontal wind speed is about $2 \mathrm{~m} \mathrm{~s}^{-1}$ on 23 December 2013. The low PBL also suppresses the vertical dispersion in the basin. On 2 December 2013 ("transition"), the basin is influenced by the trough in the north and the high in the south on $850 \mathrm{hPa}$, and the variation of meteorological conditions inside the basin is determined by the development of the trough and the high. From early morning to noontime, the wind gradually gets stronger, indicating the deepening of the trough in the north and possible venting of pollutants from the basin. The increasing winds in the evening also induce high PBL, enhancing the pollutants mixing in the vertical direction. In general, the synoptic pattern influencing the basin experience the transition from "inlandhigh" to "southwest-trough", so that the pollutants accumulated in the basin in the morning have potentials to be transported outside of the basin in the afternoon/evening, depending on the deepening of the trough in the north at $850 \mathrm{hPa}$.

Figure 9 presents the observed and simulated spatial distributions of near-surface $\mathrm{PM}_{2.5}$ mass concentrations along with the modeled wind fields in the Guanzhong basin at 09:00 and 15:00 BJT on the selected 6 days. The calculated patterns of $\mathrm{PM}_{2.5}$ mass concentrations are generally consistent with the observation over the ambient monitoring sites on those days. Under the favorable situations, the strong northern or northwestern winds have commenced to evacuate the air pollutants accumulated during nighttime at 09:00 BJT (Fig. 8b and c), and the whole basin becomes clean at 15:00 BJT. In case of unfavorable situations, the near-surface winds in the basin are weak or calm and frequently disordered, which facilitates the accumulation of air pollutants, causing heavy air pollution. The modeled and observed $\mathrm{PM}_{2.5}$ mass concentrations exceed $150 \mu \mathrm{g} \mathrm{m}^{-3}$ at

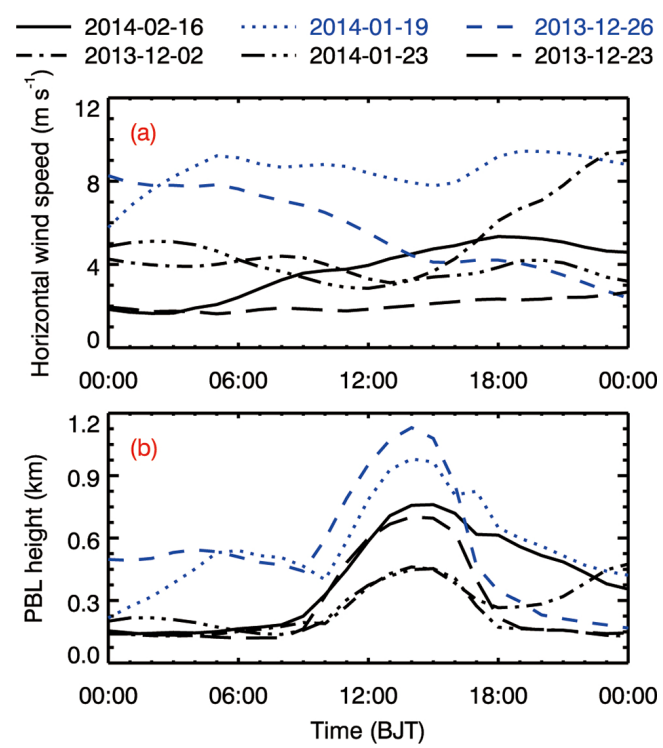

Figure 8. Temporal variations of the area averaged low-level (a) wind speeds and (b) PBL height over the basin on 16 February 2014 ("north-low"), 19 January 2014 ("southwest-trough"), 26 December 2013 ("southeast-high"), 2 December 2013 ("transition"), 23 January 2014 ("southeast-trough"), and 23 December 2013 ("inland-high").

most of the monitoring sites. Particularly, on 23 December 2013 ("inland-high"), the basin experienced severe air pollution with the $\mathrm{PM}_{2.5}$ mass concentrations exceeding 250 or even $500 \mu \mathrm{g} \mathrm{m}^{-3}$ at the monitoring sites. On 23 January 2014 ("southeast-trough"), the near-surface south winds over Qinling Mountains are not weak, but, apparently, the warm and humid air from the south does not significantly influence the wind fields in the basin. Unfortunately, the south winds over the Qinling Mountains carry the warm air aloft the basin, causing temperature inversion and further hindering the diffusion of air pollutants in the vertical direction (Fig. 6e). Therefore, under the condition of "southeast-trough", the whole basin seems to be sealed and is often severely polluted; i.e., the 5-year average filter measured $\mathrm{PM}_{2.5}$ mass concentration exceeds $300 \mathrm{\mu g} \mathrm{m}^{-3}$ at the IEECAS site (Fig. 5). Figure 10 presents the comparison of observed and predicted diurnal profiles of the $\mathrm{PM}_{2.5}$ mass concentrations averaged over the monitoring sites in the Guanzhong basin on the selected 6 days. The WRF-CHEM model generally captures well the observed diurnal variations of the $\mathrm{PM}_{2.5}$ mass concentrations, but the model simulations tend to underestimate the $\mathrm{PM}_{2.5}$ concentrations when the levels are high. The model biases are mainly from the uncertainties of anthropogenic emissions and meteorological field simulations. The model often underestimates the observed $\mathrm{PM}_{2.5}$ mass concentrations during nighttime, which perhaps is caused by illegal emissions that are not reflected in the available emission inventories. In addition, in the afternoon on 23 December 2013, the model considerably underestimates the observa- 

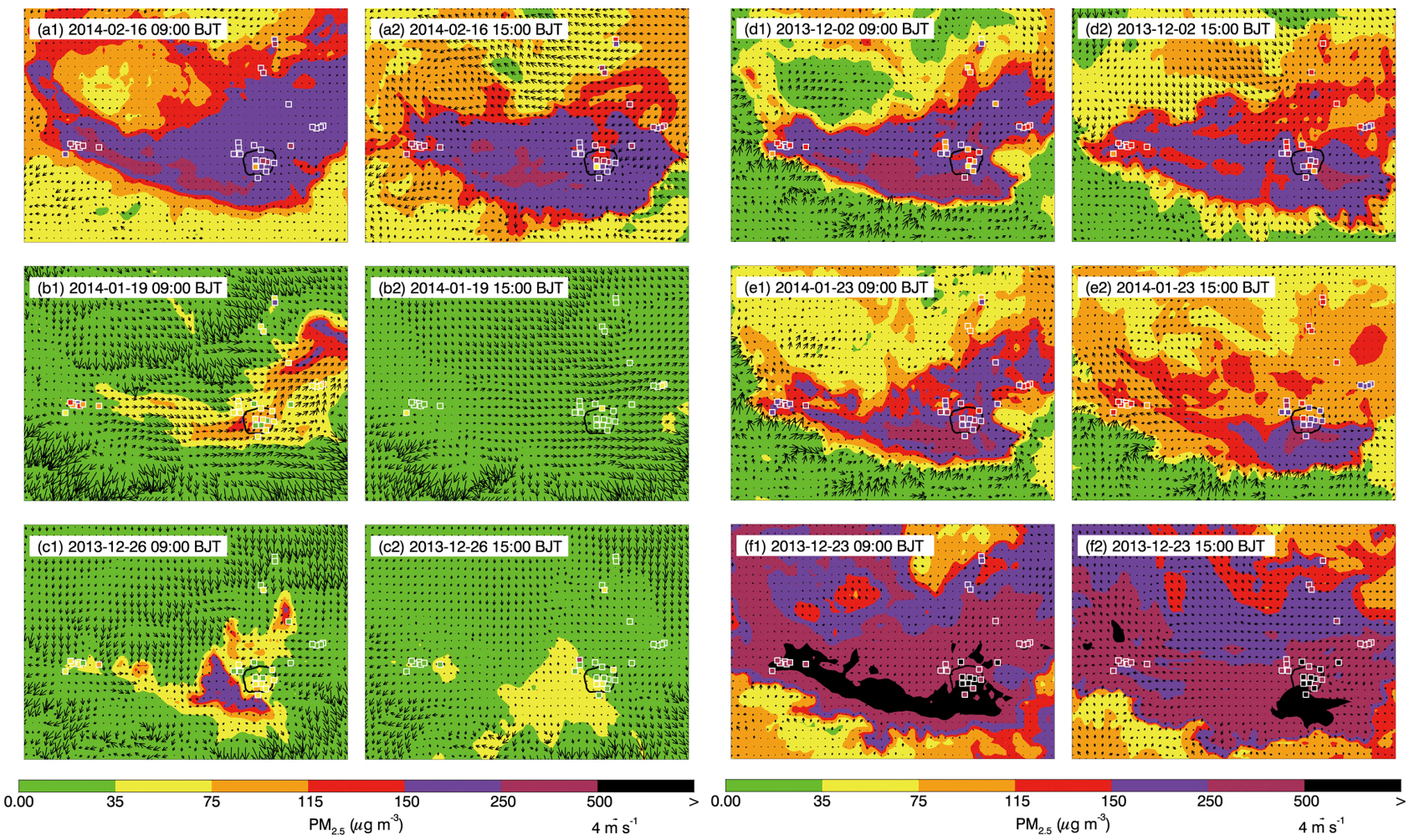

Figure 9. Pattern comparison of simulated vs. observed near-surface $\mathrm{PM}_{2.5}$ mass concentrations at 09:00 and 15:00 BJT on (a) 16 February 2014 ("north-low"), (b) 19 January 2014 ("southwest-trough"), (c) 26 December 2013 ("southeast-high"), (d) 2 December 2013 ("transition"), (e) 23 January 2014 ("southeast-trough"), and (f) 23 December 2013 ("inland-high"). Colored squares: PM$_{2.5}$ observations; color contour: $\mathrm{PM}_{2.5}$ simulations; black arrows: simulated surface winds.
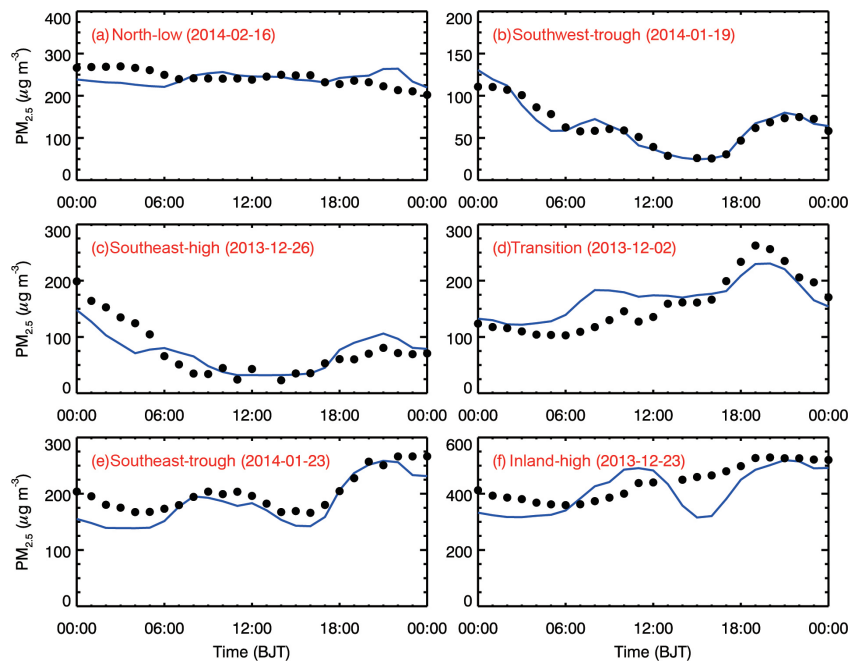

Figure 10. Comparison of observed and predicted diurnal profiles of the $\mathrm{PM}_{2.5}$ mass concentrations averaged over the monitoring sites in the Guanzhong basin on (a) 16 February 2014 ("northlow"), (b) 19 January 2014 ("southwest-trough"), (c) 26 December 2013 ("southeast-high"), (d) 2 December 2013 ("transition"), (e) 23 January 2014 ("southeast-trough"), and (f) 23 December 2013 ("inland-high"). tion. According to Fig. 9f, the simulated northeast winds are subject to pushing the plume to the south of the basin, causing the model underestimation compared to measurements. Under favorable synoptic situations, the average $\mathrm{PM}_{2.5}$ mass concentrations over the monitoring sites are significantly decreased from the early morning to the late afternoon, and the air quality can reach a good level during daytime. However, under the conditions of unfavorable synoptic situations, the average $\mathrm{PM}_{2.5}$ mass concentrations do not decrease as much or even increase in the afternoon when the PBL well develops. The unfavorable synoptic situations generally induce the stagnant circumstances, retaining the air pollutants inside the basin. In the afternoon with the peak of sunlight, the elevated air pollutants, including the precursors of secondary aerosols, cause the rapid formation of secondary aerosols, such as nitrate and SOA, compensating the decrease of $\mathrm{PM}_{2.5}$ mass concentrations due to the development of the PBL. Furthermore, high levels of aerosols in the low-level atmosphere also scatter the solar radiation and reduce the surface temperature, suppressing the development of the PBL. So the formation of secondary aerosols and the aerosol radiation feedback likely lead to high $\mathrm{PM}_{2.5}$ mass concentrations in the afternoon, under unfavorable synoptic situations. Figure 11a displays a scatter plot of the measured vs. modeled daily mean 

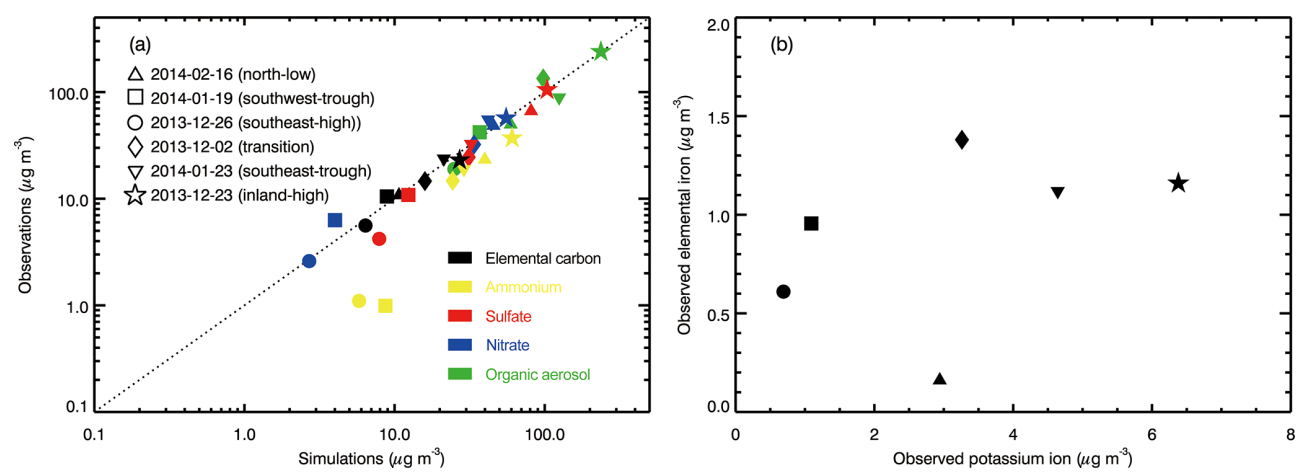

Figure 11. Scatter plot of (a) the measured vs. modeled daily mean mass concentration of aerosol constituents and (b) the elemental iron with potassium measured by filter samples at IEECAS site on the selected 6 days.

mass concentration of major aerosol constituents at IEECAS site on the selected 6 days. The filter-measured organic carbon is scaled by a factor of 1.8 to compare with the simulated organic aerosol (Carlton et al., 2010). The WRF-CHEM model performs reasonably well in simulating daily mean sulfate, ammonium, organic aerosols, and elemental carbon. However, the model consistently overestimates the observed ammonium aerosol mass concentration. The filter measurements show that the $\mathrm{PM}_{2.5}$ in the basin contains abundant potassium, sodium, and calcium ions which are originated from biomass burning or dust and are able to preferentially replace the ammonium ions (Shen et al., 2009, 2011). Figure $11 \mathrm{~b}$ shows the scatter plot of the elemental iron with potassium measured by filter samples at the IEECAS site on the selected 6 days. In general, the elemental iron is primarily originated from dust and the potassium is mainly attributed by biomass burning. Under unfavorable conditions, the potassium concentration exceeds $3 \mu \mathrm{g} \mathrm{m}^{-3}$, showing considerable amount of biomass burning. Except on 16 February the elemental iron concentration is also high, ranging from 0.5 to $1.5 \mu \mathrm{g} \mathrm{m}^{-3}$, likely caused by the local production or long-range transport from Loess Plateau (Long et al., 2016). On 16 February the trace precipitation did not wash out pollutants efficiently but did moisten the ground surface in the basin, hindering the dust production. In the WRF-CHEM simulations, the contributions of potassium, sodium, and calcium ions are not considered due to lack of available emissions inventories; thus when there is sufficient ammonia concentration in the atmosphere, this can lead to overestimation of ammonium aerosols. In general, the simulated $\mathrm{PM}_{2.5}$ patterns and variations on the selected 6 days are consistent with the corresponding synoptic situations.

\section{Conclusions and discussions}

In the present study, the typical synoptic situations influencing the Guanzhong basin during wintertime have been investigated to evaluate their potential impacts on the air quality in the basin by using NCEP reanalysis data, aerosol measurements, and simulations by the FLEXPART, WRF, and WRFCHEM models. The results show that the synoptic situations significantly contribute to the air pollution in the basin during wintertime.

Based on the NCEP reanalysis data, the large-scale synoptic situations influencing the Guanzhong basin during the wintertime of 2013 are categorized into six types, which are "north-low", "southwest-trough", "southeast-high", "transition", "southeast-trough", and "inland-high". The FLEXPART trajectory model has been utilized to examine the corresponding pollutant transport patterns for the typical synoptic situations in the basin. The pollutants are transported outside of the basin under "southwest-trough" and "southeasthigh", which are defined as favorable synoptic situations. The remaining four types of synoptic conditions, defined as unfavorable synoptic situations, are subject to pollutant accumulation in the basin, causing heavy air pollution. In association with the $\mathrm{PM}_{2.5}$ measurements released by China MEP, the low $\mathrm{PM}_{2.5}$ level or good air quality generally correspond to the favorable synoptic situations and vice versa in the basin.

Analysis of the large-scale synoptic situations of the wintertime during 2008 to 2012 shows that unfavorable synoptic situations constitute about $85 \%$ of the winter days, indicating significant contribution from the large-scale meteorological conditions to the poor air quality in the Guanzhong basin. In addition, the percentage of "inland-high" is around $42 \%$, which is the most frequent synoptic situation associated with poor air quality in the basin.

The WRF-CHEM model has been further used to simulate the selected 6 days representing the typical synoptic situations during the wintertime of 2013, and the results show that the modeled $\mathrm{PM}_{2.5}$ distribution and variations are generally consistent with the corresponding synoptic conditions, which demonstrates the critical role of the synoptic meteorological conditions in air pollution events in the basin. The WRFCHEM model simulations also indicate reasonable classification for the synoptic situations in the basin. In addition, de- 
tailed meteorological conditions, including temperature inversion, low-level horizontal wind speed, and PBL height, are also analyzed for the selected days. Under unfavorable synoptic situations, temperature inversion, weak low-level wind, and low PBL do not facilitate the dispersion of pollutants in the basin. In contrast, under the favorable synoptic situations, strong horizontal winds and high PBL efficiently vent the air pollutants from the basin.

During wintertime, 5-year filter $\mathrm{PM}_{2.5}$ measurements from 2008 to 2012 and the $\mathrm{PM}_{2.5}$ measurements released by China MEP in 2013 and 2014 all show that the Guanzhong basin has experienced heavy air pollution. Even under favorable synoptic situations, the observed $\mathrm{PM}_{2.5}$ mass concentrations have barely reached the "excellent" level due to massive local emissions of air pollutants and the background dust transported from Loess Plateau. Thus, considering the proportion of occurrence of unfavorable synoptic situations during wintertime, reduction of emissions is a feasible method to reduce the air pollution in the Guanzhong basin.

Given that the categorization of synoptic situations are made at $850 \mathrm{hPa}$ that influence the Guanzhong basin, potential uncertainties still exist in the classification results. More quantitative studies are needed in the future to improve the synoptic situation classification. Further, the analysis using local meteorological observations on ground surfaces and inside the PBL is also imperative for investigating the role of the local meteorological conditions during severe pollution events.

\section{Data availability}

The real-time $\mathrm{O}_{3}, \mathrm{NO}_{2}$, and $\mathrm{PM}_{2.5}$ are accessible to the public on the website http://106.37.208.233:20035/. One can also access the historic profile of observed ambient pollutants through visiting http://www.aqistudy.cn/.

Acknowledgements. Naifang Bei is supported by the National Natural Science Foundation of China (nos. 41275101 and 41430424) and the Fundamental Research Funds for the Central Universities of China. Guohui Li is supported by "Hundred Talents Program" of the Chinese Academy of Sciences and the National Natural Science Foundation of China (no. 41275153).

Edited by: R. Volkamer

\section{References}

Bei, N., de Foy, B., Lei, W., Zavala, M., and Molina, L. T.: Using 3DVAR data assimilation system to improve ozone simulations in the Mexico City basin, Atmos. Chem. Phys., 8, 7353-7366, doi:10.5194/acp-8-7353-2008, 2008.
Bei, N., Lei, W., Zavala, M., and Molina, L. T.: Ozone predictabilities due to meteorological uncertainties in the Mexico City basin using ensemble forecasts, Atmos. Chem. Phys., 10, 6295-6309, doi:10.5194/acp-10-6295-2010, 2010.

Bei, N., Li, G., and Molina, L. T.: Uncertainties in SOA simulations due to meteorological uncertainties in Mexico City during MILAGRO-2006 field campaign, Atmos. Chem. Phys., 12, 11295-11308, doi:10.5194/acp-12-11295-2012, 2012.

Bei, N., Li, G., Zavala, M., Barrera, H., Torres, R., Grutter, M., Gutiérrez, W., García, M., Ruiz-Suarez, L. G., Ortinez, A., Guitierrez, Y., Alvarado, C., Flores, I., and Molina, L. T. : Meteorological overview and plume transport patterns during CalMex 2010, Atmos. Environ., 70, 477-489, 2013.

Binkowski, F. S. and Roselle, S. J.: Models-3 Community Multiscale Air Quality (CMAQ) model aerosol component: 1. Model description, Journal of Geophysical Research, J. Geophys. Res., 108, 4183, doi:10.1029/2001JD001409, 2003.

Cao, J. J., Zhu, C. S., Chow, J. C., Waston, J. G., Han, Y. M., Wang, G., Shen, Z., and An, Z.: Black carbon relationships with emissions and meteorology in Xi' an, China, Atmos. Res., 94, 194 202, 2009.

Cao, J. J., Wang, Q. Y., Chow, J. C., Watson, J. G., Tie, X., Shen, Z., Wang, P., and An, Z: Impacts of aerosol compositions on visibility impairment in Xi'an, China, Atmos. Environ., 59, 559-566, 2012.

Carlton, A. G., Bhave, P. V., Napelenok, S. L., Edney, E. O., Sarwar, G., Pinder, R. W., Pouliot, G. A., and Houyoux, M.: Model Representation of Secondary Organic Aerosol in CMAQv4.7, Environ. Sci. Technol., 44, 8553-8560, doi:10.1021/es100636q, 2010.

Chan, C. K. and Yao, X.: Air pollution in mega cities in China, Atmos. Environ., 42, 1-42, 2008.

Chen, Z., Cheng, S., Li, J., Guo, X., Wang, W., and Chen, D.: Relationship between atmospheric pollution processes and synoptic pressure patterns in Northern China, Atmos. Environ., 42, 6078 6087, 2008.

Cheng, W. L., Pai, J. L., Tsuang, B. J., and Chen, C. L.: Synoptic patterns in relation to ozone concentrations in West-Central Taiwan, Meteorol. Atmos. Phys., 78, 11-21, 2001.

de Foy, B., Caetano, E., Magaña, V., Zitácuaro, A., Cárdenas, B., Retama, A., Ramos, R., Molina, L. T., and Molina, M. J.: Mexico City basin wind circulation during the MCMA-2003 field campaign, Atmos. Chem. Phys., 5, 2267-2288, doi:10.5194/acp-52267-2005, 2005.

de Foy, B., Varela, J. R., Molina, L. T., and Molina, M. J.: Rapid ventilation of the Mexico City basin and regional fate of the urban plume, Atmos. Chem. Phys., 6, 2321-2335, doi:10.5194/acp-6-2321-2006, 2006.

Fang, M., Chan, C. K., and Yao, X. H.: Managing air quality in a rapidly developing nation: China, Atmos. Environ., 43, 79-86, 2009.

Fast, J. and Easter, R.: A Lagrangian Particle Dispersion Model Compatible with WRF, 2006. 7th WRF Users Workshop, NCAR, 19-22 June 2006, Boulder, Colorado, USA, 2006.

Fu, G. Q., Xu, W. Y., Yang, R. F., Li, J. B., and Zhao, C. S.: The distribution and trends of fog and haze in the North China Plain over the past 30 years, Atmos. Chem. Phys., 14, 11949-11958, doi:10.5194/acp-14-11949-2014, 2014. 
Gao, Y., Liu, X., Zhao, C., and Zhang, M.: Emission controls versus meteorological conditions in determining aerosol concentrations in Beijing during the 2008 Olympic Games, Atmos. Chem. Phys., 11, 12437-12451, doi:10.5194/acp-11-12437-2011, 2011.

Grell, G. A. and Devenyi, D.: A generalized approach to parameterizing convection combining ensemble and data assimilation techniques, Geophys. Res. Lett., 29, 38-1-38-4, doi:10.1029/2002GL015311, 2002.

Grell, G. A., Peckham, S. E., Schmitz, R., McKeen, S. A., Wilczak, J., and Eder, B.: Fully coupled "online" chemistry within the WRF model, Atmos. Environ., 39, 6957-6975, 2005.

Guenther, A., Karl, T., Harley, P., Wiedinmyer, C., Palmer, P. I., and Geron, C.: Estimates of global terrestrial isoprene emissions using MEGAN (Model of Emissions of Gases and Aerosols from Nature), Atmos. Chem. Phys., 6, 3181-3210, doi:10.5194/acp-63181-2006, 2006.

Guo, S., Hu, M., Zamora, M. L., Peng, J., Shang, D., Zheng, J., Du, Z., Wu, Z., Shao, M., Zeng, L., Molina, M. J., and Zhang, R.: Elucidating severe urban haze formation in China, P. Natl. Acad. Sci. USA, 111, 17373-17378, 2014.

Han, S., Wu, J., Zhang, Y., Cai, Z., Feng, Y., Yao, Q., Li, X., Liu, Y., and Zhang, M.: Characteristics and formation mechanism of a winter hazeefog episode in Tianjin, China, Atmos. Environ., 98, 323-330, 2014.

Hong, S.-Y., Dudhia, J., and Chen, S.-H.: A revised approach to ice microphysical processes for the bulk parameterization of clouds and precipitation, Mon. Weather Rev., 132, 103-120, 2004.

Horowitz, L. W., Waters, S., Mauzerall, D. L., Emmons, L. K., Rasch, P. J., Tie, X., Lamarque, J.-F., Schultz, M. G., Tyndall, G. S., Orlando, J. J., and Brasseur, G. P.: A global simulation of tropospheric ozone and related tracers: Description and evaluation of MOZART, version 2, J. Geophys. Res., 108, 4784, doi:10.1029/2002JD002853, 2003.

Huang, R. J., Zhang, Y. L., Bozzetti, C., Ho, K. F., Cao, J. J., Han, Y. M., Dällenbach, K. R., Slowik, J. G., Platt, S. M., Canonaco, F., Zotter, P., Wolf, R., Pieber, S. M., Bruns, E. A., Crippa, M., Ciarelli, G., Piazzalunga, A., Schwikowski, M., Abbaszade, G., Schnelle-Kreis, J., Zimmermann, R., An, Z. S., Szidat, S., Baltensperger, U., EI Haddad, I., and Prévôt, A. S. H.: High secondary aerosol contribution to particulate pollution during haze events in China, Nature, 514, 218-222, 2014.

Huth, R., Beck, C., Philipp, A., Demuzere, M., Ustrnul, Z., Cahynová, M., Kyselý, J., and Tveito, O. E.: Classifications of atmospheric circulation patterns, Ann. NY Acad. Sci., 1146, 105152,2008

Jacobeit, J.: Classifications in climate research, Phys. Chem. Earth, 35, 411-421, 2010.

Janjic, Z. I.: Nonsingular implementation of the Mellor-Yamada level 2.5 scheme in the NCEP Meso Model, NCEP Office Note, 437, College Park, MD, USA, 61 pp., 2002.

Li, G., Lei, W., Zavala, M., Volkamer, R., Dusanter, S., Stevens, P., and Molina, L. T.: Impacts of HONO sources on the photochemistry in Mexico City during the MCMA-2006/MILAGO Campaign, Atmos. Chem. Phys., 10, 6551-6567, doi:10.5194/acp-106551-2010, 2010.

Li, G., Bei, N., Tie, X., and Molina, L. T.: Aerosol effects on the photochemistry in Mexico City during MCMA2006/MILAGRO campaign, Atmos. Chem. Phys., 11, 51695182, doi:10.5194/acp-11-5169-2011, 2011a.
Li, G., Zavala, M., Lei, W., Tsimpidi, A. P., Karydis, V. A., Pandis, S. N., Canagaratna, M. R., and Molina, L. T.: Simulations of organic aerosol concentrations in Mexico City using the WRFCHEM model during the MCMA-2006/MILAGRO campaign, Atmos. Chem. Phys., 11, 3789-3809, doi:10.5194/acp-11-37892011, 2011b.

Li, G., Lei, W., Bei, N., and Molina, L. T.: Contribution of garbage burning to chloride and $\mathrm{PM}_{2.5}$ in Mexico City, Atmos. Chem. Phys., 12, 8751-8761, doi:10.5194/acp-12-8751-2012, 2012.

Liu, X. G., Li, J., Qu, Y., Han, T., Hou, L., Gu, J., Chen, C., Yang, Y., Liu, X., Yang, T., Zhang, Y., Tian, H., and Hu, M.: Formation and evolution mechanism of regional haze: a case study in the megacity Beijing, China, Atmos. Chem. Phys., 13, 4501-4514, doi:10.5194/acp-13-4501-2013, 2013.

Long, X., Li, N., Tie, X., Cao, J., Zhao, S., Huang, R., Zhao, M., Li, G., and Feng, T.: Urban dust in the Guanzhong Basin of China, part I: A regional distribution of dust sources retrieved using satellite data, Sci. Total Environ., 541, 1603-1613, 2016.

Ministry of Environmental Protection, China (China MEP): Air Quality Observation Real-time Release Platform of MEP Data Center, available at: http://106.37.208.233:20035/ (last access: 14 June 2016), 2013a.

Ministry of Environmental Protection, China (China MEP): Online Monitoring and Analysis Platform of China Air Quality, available at: http://www.aqistudy.cn/ (last access: 14 June 2016), 2013b.

Penner, J. P., Andreae, M., Annegarn, H., et al.: Aerosols, their direct and indirect effects, in: Climate Change 2001: The Scientific Basis. Contribution of Working Group I to the Third Assessment Report of the Intergovernmental Panel on Climate Change, edited by: Houghton, J. T., Ding, Y., Griggs, D. J., Noguer, M., Van der Linden, P. J., Dai, X., Maskell, K., and Johnson, C. A., Cambridge University Press, Cambridge, UK, 289-348, 2001.

Philipp, A., Bartholy, J., Beck, C., Erpicum, M., Esteban, P., Fettweis, X., Huth, R., James, P., Jourdain, S., and Kreienkamp, F.: COST733CAT-a database of weather and circulation type classifications, Phys. Chem. Earth, 35, 360-373, 2010.

Pope III, C. A. and Dockery, D. W.: Health effects of fine particulate air pollution: lines that connect, J. Air Waste Manage., 56, 709742, 2006.

Seaman, N. L.: Meteorological modeling for air-quality assessments, Atmos. Environ., 34, 2231-2259, 2000.

Shen, Z., Cao, J., Arimoto, R., Han, Z., Zhang, R., Han, Y., Liu, S., Okuda, T., Nakao, S., and Tanaka, S.: Ionic composition of TSP and PM2.5 during dust storms and air pollution episodes at Xi' an, China, Atmos. Environ., 43, 2911-2918, 2009.

Shen, Z. X., Cao, J. J., Arimoto, R., Han, Y., Zhu, C., Tian, J., and Liu, S.: Chemical characteristics of fine particles $\left(\mathrm{PM}_{1}\right)$ over Xi' an, China, Aerosol Sci. Tech., 44, 461-472, 2010.

Shen, Z. X., Cao, J. J., Liu, S. X., Zhu, C., Wang, X., Zhang, T., Xu, $\mathrm{H}$., and $\mathrm{Hu}$, T.: Chemical composition of $\mathrm{PM}_{10}$ and $\mathrm{PM}_{2.5} \mathrm{col}-$ lected at ground level and 100-m during a strong winter-time pollution episode in Xi'an, China, J. Air Waste Manage., 61, 11501159, 2011.

Skamarock, W. C., Klemp, J. B., Dudhia, J., Gill, D. O., Barker, D. M., Duda, M., Huang, X.-Y., Wang, W., and Powers, J. G.: A Description of the Advanced Research WRF Version 3, NCAR Technical Note, Boulder, CO, USA, 2008. 
Solomon, P., Cowling, E., Hidy, G., and Furiness, C.: Comparison of scientific findings from major ozone field studies in North America and Europe, Atmos. Environ., 34, 1885-1920, 2000.

Stohl, A., Hittenberger, M., and Wotawa, G.: Lagrangian particle dispersion model FLEXPART against large scale tracer experiment data, Atmos. Environ., 32, 4245-4264, 1998.

Wang, H., Xu, J., Zhang, M., Yang, Y., Shen, X., Wang, Y., Chen, D., and Guo, J.: A study of the meteorological causes of a prolonged and severe haze episode in January 2013 over centraleastern China, Atmos. Environ., 98, 146-157, 2014.

Wang, L., Zhang, N., Liu, Z., Sun, Y., Ji, D., and Wang, Y.: The Influence of Climate Factors, Meteorological Conditions, and Boundary-Layer Structure on Severe Haze Pollution in the Beijing-Tianjin-Hebei Region during January 2013, Adv. Meteorol., 2014, 1-14, 2014.

Wang, Y., Hao, J., McElroy, M. B., Munger, J. W., Ma, H., Chen, D., and Nielsen, C. P.: Ozone air quality during the 2008 Beijing Olympics: effectiveness of emission restrictions, Atmos. Chem. Phys., 9, 5237-5251, doi:10.5194/acp-9-5237-2009, 2009.

Wei, P., Cheng, S., Li, J., and Su, F.: Impact of boundary-layer anticyclonic weather system on regional air quality, Atmos. Environ., 45, 2453-2463, 2011.

Wu, D., Liao, G., Deng, X., Bi, X., Tan, H., Li, F., Jiang, C., Xia, D., and Fan, S.: Transport Condition of Surface Layer Under Haze Weather over the Pearl River Delta, J. Appl. Meteor. Sci., 19, 1-9, 2008 (in Chinese).

Wu, M., Wu, D., Fan, Q., Wang, B. M., Li, H. W., and Fan, S. J.: Observational studies of the meteorological characteristics associated with poor air quality over the Pearl River Delta in China, Atmos. Chem. Phys., 13, 10755-10766, doi:10.5194/acp13-10755-2013, 2013.
Yang, Y., Liu, X., Qu, Y., Wang, J., An, J., Zhang, Y., and Zhang, F.: Formation mechanism of continuous extreme haze episodes in the megacity Beijing, China, in January 2013, Atmos. Res., 155, 192-203, 2015.

Zhang, J., Mauzerall, D. L., Zhu, T., Liang, S., Ezzati, M., and Remais, J. V.: Environmental health in China: progress towards clean air and safe water, The Lancet, 375, 1110-1119, 2010.

Zhang, J. P., Zhu, T., Zhang, Q. H., Li, C. C., Shu, H. L., Ying, Y., Dai, Z. P., Wang, X., Liu, X. Y., Liang, A. M., Shen, H. X., and Yi, B. Q.: The impact of circulation patterns on regional transport pathways and air quality over Beijing and its surroundings, Atmos. Chem. Phys., 12, 5031-5053, doi:10.5194/acp-12-50312012, 2012.

Zhang, Q., Streets, D. G., Carmichael, G. R., He, K. B., Huo, H., Kannari, A., Klimont, Z., Park, I. S., Reddy, S., Fu, J. S., Chen, D., Duan, L., Lei, Y., Wang, L. T., and Yao, Z. L.: Asian emissions in 2006 for the NASA INTEX-B mission, Atmos. Chem. Phys., 9, 5131-5153, doi:10.5194/acp-9-5131-2009, 2009.

Zhang, Q., Quan, J., Tie, X., Li, X., Liu, Q., Gao, Y., and Zhao, D.: Effects of meteorology and secondary particle formation on visibility during heavy haze events in Beijing, China, Sci. Total Environ., 502, 578-584, 2015.

Zhang, Q. H., Zhang, J. P., and Xue, H. W.: The challenge of improving visibility in Beijing, Atmos. Chem. Phys., 10, 78217827, doi:10.5194/acp-10-7821-2010, 2010.

Zhao, X. J., Zhao, P. S., Xu, J., Meng,, W., Pu, W. W., Dong, F., He, D., and Shi, Q. F.: Analysis of a winter regional haze event and its formation mechanism in the North China Plain, Atmos. Chem. Phys., 13, 5685-5696, doi:10.5194/acp-13-5685-2013, 2013. 